\title{
THE HISTORY OF THE DEVELOPMENT OF THE LEGISLATION OF AZERBAIJAN ON REAL ESTATE PROPERTY (60-90S OF THE XX CENTURY)
}

\author{
DADASHOV Emin Teyyub - PhD in law, Senior researcher at the Institute of \\ Law and Human Rights of the Azerbaijan National Academy of Sciences \\ DOI 10.32782/LAW.UA.2021.2.19
}

The article notes that in the last years of the existence of the USSR, starting from the middle of 1989, the sale of apartments in the houses of the state and public housing stock to citizens in personal ownership began in Azerbaijan. In the "Constitutional Act on the Restoration of State Independence of the Republic of Azerbaijan" dated October 18, 1991, in Articles 7 and 22, the term real estate was used for the first time.

Keywords: Law, code, article, property, history, legislation.

If we look at the history of the development of legislation on the institution of "real estate" as a legal category, we see that in the 60s of the twentieth century in the legislation of Azerbaijan, being one of the Soviet Socialist Republics, as well as in the Civil Legislation of the USSR and the allied republics there was no division of property as immovable and movable.

Although the term real estate is not reflected in the Civil Code of the Soviet Socialist Republic of Azerbaijan, adopted on September 11, 1964 and entered into force on March 1, 1965, residential real estate (apartments, houses, etc.) relations were reguated by this Code. Chapter 29 of the mentioned Code was entitled "Apartment rent" and 46 articles (Articles 299344) reflected in this chapter regulated relations related to living space.

Article 299 of the Code, entitled «Rules for the provision of housing» stated: "Provision of apartments in the houses of local Soviets of People's Deputies is provided by the executive committee of the local Soviet with the participa- tion of representatives of public organizations, and in the houses of state and cooperative organizations by a joint decision of the executive committee of the local committee of factories, plants and trade unions.

According to the decision to rent the apartment, the executive committee of the local Soviet of Workers' Deputies issues a Housing Allocation Order-Permit to move in.

An order issued in violation of the rules established by this article may be considered invalid by a court» $[1$, p. 415].

Article 301 of the Civil Code of 11 September 1964 stated that «the housing department must enter into a written agreement with the person in whose name the Order is issued for the rent of the apartment specified in the Order.

In the houses of local Soviets of People's Deputies, as well as in the houses of state, cooperative and public organizations, the apartment lease agreement is concluded with the consent of the parties, as a rule, without specifying the term, unless otherwise specified.

A member of a housing cooperative may rent an apartment in the cooperative's house with the consent of the board.

In houses owned by citizens on the basis of private property rights, an apartment lease agreement is concluded between the tenant and the owner of the house, and the term of the lease agreement is determined by agreement of the parties.

The lease agreement for a service apartment is concluded for the entire period of the 


\section{Цивільне, підприсмницьке, господарське та трудове право}

lessee's employment in the organization renting the apartment.

The agreement defines the rights and obligations of the parties».

In the houses of local Soviets of People's Deputies, state, cooperative organizations and public organizations, the subject of the apartment lease agreement could be a separate apartment consisting of only one or more rooms. In one house, the lease of a part of a room or a separate room combined with other rooms (mixed rooms) with a common entrance was not allowed.

Auxiliary constructions (kitchens, corridors, warehouses, etc.) of apartments in the houses of local Soviets of People's Deputies, state, cooperative organizations and public organizations were given to all tenants and their family members living in the apartment with equal rights and could not be the subject of an independent lease.

With the written consent of all the adult members of his family living in the same house, the tenant could move his husband (wife), children, parents, other relatives and dependents to the rented apartment in the prescribed manner. The consent of the rest of the family was not required for the transfer of minors to their parents' apartment.

The tenant's wife (husband), their children and parents were considered members of the tenant's family. Other relatives, as well as dependents with disabilities, could be considered members of the tenant's family if they lived with the tenant and shared a household with him.

If there are no family members living in the apartment of the conscript, the lessee may lease the apartment to other citizens under the lease agreement during the period of military service, three months after the date of his conscription. The serviceman was entitled to demand the immediate release of the apartment and his relocation upon his return from military service.

For tenants of apartments in the houses of the Soviets of People's Deputies or in the houses of state, cooperative and public organizations, the norm of living space was set at 12 (twelve) square meters per person.

The second part of Article 101 of the Civil Code of September 11, 1964, stipulates that a couple living together and their minor children may own a dwelling house or a part of it, which belongs to one of them or is in the common property of all of them.

Article 103 of the same Code, entitled «Consequences of Acquisition of a House on the Private Property Rights of a Citizen Who Owns an Apartment in a Housing Cooperative» stated that «if a citizen or a spouse living together and their minor children have a dwelling house or part of a house on the grounds permitted by law in the right of private property, and the apartment of a housing cooperative, the owner shall own one of them, or the house (part of the house), or the apartment in the house of the housing cooperative. In the latter case, the owner must alienate his house (part of the house) within one year from the date of the right of ownership of the house (part of the house) or from the day of moving to the apartment of the housing cooperative. If this requirement is not met, the house (part of the house) must be forcibly alienated».

The analogue of the provisions reflected in Articles 101 and 103 of the Civil Code of the Azerbaijan SSR was established in Articles 106 and 108 of the Civil Code of the RSFSR of June 11, 1964. Commenting on these articles, Ryasentsev V.A. and Shakhmatov V.P. rightly pointed out that, «if the couple lives in different cities or separately, then each of them can own a dwelling house» [2, p. 55; 3, p. 130].

According to Article 230 of the Civil Code, if at least one of the parties is an individual, the contract of purchase of the dwelling house was required to be notarized, if both parties acted as legal entities during the contract of puschase of the dwelling, which is a type of real estate, notarization of contracts was not mandatory, the parties could notarize such contracts only if they wished.

In the early 1970 s, there was a need to develop a new Constitution. The Constitution was adopted on October 7, 1977, after the completion of work on a new, third draft Constitution in the Soviet Union. The 1977 Constitution of the USSR stated that the main housing stock of cities belonged to the state (Article 11), that citizens could own a house (Article 13), and for the first time Article 44 stated that citizens of the USSR had the right to housing [4]. 
After the entry into force of the USSR Constitution of October 7, 1977, on April 21, 1978, the fourth extraordinary session of the Supreme Soviet of the Azerbaijan SSR adopted the fourth Constitution (Main Law) of the Azerbaijan Soviet Socialist Republic, consisting of 11 sections, 22 chapters and 185 articles. Article 42 of the Constitution stated that "citizens of the Azerbaijan SSR have the right to housing. This right is ensured by the development and protection of the state and public housing stock, assistance in the construction of cooperative and individual housing, the fair distribution of housing under public control during the implementation of the comfortable housing program, as well as low housing and utility bills. Citizens of the Azerbaijani SSR should take care of the apartment given to them" [5].

V.N. Litovkin rightly points out that "the fact that the Constitution of the USSR and the constitutions of the allied republics reflected the right of citizens of the USSR to housing increased the level of legal regulation of housing relations" [6, p. 72].

We would like to note that the proper resolution of disputes related to the change of residence by the courts was one of the factors that helped to improve the living conditions of citizens protected by the Constitution. However, the courts violated the laws governing the consideration of such cases. In order to eliminate the shortcomings in housing changes, the Plenum of the Supreme Court of the Azerbaijan SSR on April 10, 1981 adopted Decision No. 6 , consisting of 10 paragraphs, "On the practice of application of the law by courts when considering disputes related to housing changes". Paragraphs 1 and 2 of the decision stated: "Courts need to thoroughly examine the motives for the change of housing, thoroughly examine whether the change is commercial or fraudulent, and take decisive measures to prevent abuses in the exchange of housing.

Courts need to prevent the sale of the apartment by the rule of court in the case of exchange of the housing and examine the cases of poor housing conditions of the parties in the exchange of the proposed apartments (shared flat, lack of utilities, etc.) and gaining preference of one of the parties over the other (relocation of a small family to a larger apartment, move of people to higher floors, who are unable to go upstairs due to their age or health, etc.) $[7$, p. 58].

We consider it necessary to state that the housing rights of citizens were defined in general in the Civil Code. In order to regulate housing relations in a broader form, the Supreme Soviet of the USSR adopted the Fundamentals of Housing Legislation of the USSR and the Allied Republics on June 24, 1981, and entered into force on January 1, 1982. Article 5 of the mentioned Legislation which is consisted of 56 articles, entitled "Determination of dwellings", stated that "dwellings shall be for the permanent residence of citizens, as well as for their use as service dwellings and dormitories in the prescribed manner. Provision of areas for industrial needs in dwellings is forbidden" [8;9].

In 1982-1983, the allied republics adopted the Housing Codes in accordance with the Basic Housing Legislation of the USSR and the allied republics. The Housing Code of the Azerbaijan SSR, adopted on July 8, 1982 and entered into force on March 1, 1983, consisted of 7 sections containing 149 articles. It is very positive that among the allied republics of the USSR, Azerbaijan was the first republic to adopt a housing code. For example, the Housing Code of the RSFSR was adopted on June 24, 1983 [10], the Housing Code of the Ukrainian Soviet Socialist Republic was adopted on June 30, 1983 [11], and the Housing Code of the Kazakh SSR was adopted on June 30, 1983 [12].

Article 10 of the Housing Code of the Azerbaijan SSR entitled "Citizens' housing rights and obligations" stated: "Citizens of the Azerbaijan SSR have the right to receive living space in state or public housing or housing cooperatives in the prescribed manner.

Citizens are provided with living space in state and public housing, as well as in the houses of housing cooperatives for indefinite use.

In accordance with the legislation of the USSR and the Azerbaijan SSR, citizens may own a dwelling house (part of a house).

No one may be evicted from his / her place of residence except on the grounds and in the manner prescribed by law and no one's right to use the area in which he lives may be restricted.

Citizens should take care of their homes, use living space for its intended purpose, follow 


\section{Цивільне, підприсмницьке, господарське та трудове право}

the rules of use of living space and the rules of socialist coexistence, use water, gas, electricity and heat sparingly.

Citizens may not use their homes and living quarters for personal gain, unearned income and other greedy purposes, as well as to the detriment of the public interest" [13].

Article 123 of the Housing Code of the Azerbaijan SSR, devoted to the rights and responsibilities of the family members of the owner of a dwelling house, stated that "Family members relocated by the owner of a dwelling house to his / her own house have the right to use the living space in the house together with him / her, unless otherwise specified during their relocation. The persons specified in Article 53 of this Code shall be considered family members of the owner. Family members have the right to move their minor children to the living space provided to them by the owner; resettlement of other family members is allowed only with the consent of the owner. The right of these persons to use the living space shall be retained even in the event of termination of family relations with the owner of the dwelling house.

Disputes between the owner and his family members on the rules of use of living space and the amount of participation in the expenses are resolved in court. "Article 53 of the Code stated that" the tenant's wife (husband), their children and parents are considered members of the tenant's family. Other persons living with the tenant and running a common household with him may also be considered members of the tenant's family".

For the first time, the Housing Code of the Azerbaijan SSR reflected the norms on housing cooperatives.

Article 110 of the Housing Code of the Azerbaijan SSR noted that registration of citizens wishing to join a housing construction cooperative is carried out by the decision of the executive committee of the local Council of People's Deputies at the place of residence of these citizens or by a joint decision of the administration and the trade union committee of the enterprise, institution, organization, which is organized by the cooperative, at the place of their work.

Citizens who left their jobs at these enterprises, in institutions, organizations, in connec- tion with the transition to retirement, as well as the families of workers who died as a result of an industrial accident or occupational disease, are registered on an equal basis with the workers and employees of these enterprises, institutions, organizations.

Article 111 of the Housing Code of the Azerbaijan SSR noted that the conditions for admitting citizens to members of a housing construction cooperative are established by the legislation of the USSR, this Code and other legislation of the Azerbaijan SSR.

Persons who have reached the age of 18 , permanently residing in the settlement where the housing construction cooperative is organized, and who need to improve their living conditions can be accepted to membership in a housing construction cooperative.

The legislation of the USSR may provide for other conditions and grounds for admission to membership in a housing construction cooperative.

Article 112 of the Housing Code of the Azerbaijan SSR indicated that housing-building cooperatives are organized under the appropriate administration or department of the executive committee of the local Council of People's Deputies, or at an enterprise, institution, organization. The procedure for organizing and operating housing construction cooperatives is established by the legislation of the USSR, the Model Charter of a housing construction cooperative and other legislation of the Azerbaijan SSR.

The approximate charter of a housing construction cooperative is approved by the Council of Ministers of the Azerbaijan SSR.

The housing construction cooperative operates on the basis of the charter adopted by the general meeting of persons joining the cooperative in accordance with the Model Charter of the housing construction cooperative. The charter of a housing construction cooperative is subject to registration with the executive committee of the local Council of People's Deputies at the place of organization of the cooperative. Citizens included in the list of persons joining an organized housing construction cooperative approved by the Executive Committee of the Council of People's Deputies are considered members of this cooperative from the time of 
registration of the charter. Citizens admitted to the existing housing construction cooperative are considered its members from the moment the decision of the general meeting is approved by the relevant executive committee of the Council of People's Deputies. Housing construction cooperatives operate the residential buildings they own on the basis of cooperative property rights.

Article 113 of the Housing Code of the Azerbaijan SSR said: "The executive committees of local Soviets of People's Deputies exercise control over the activities of housing-building cooperatives, over the operation and repair of their houses. The executive committee of the district, city, district in the city of the Council of People's Deputies has the right to cancel the decision of the general meeting or the board of the cooperative, if it is contrary to the law".

Articles 118-137 of the Housing Code of the Azerbaijan SSR were devoted to the use of living space in individual housing stock houses. Article 118 of the Code stated that citizens who own a dwelling house (part of a house) use it for personal living and for the living of family members. They have the right to relocate other citizens to that house (part of the house), as well as to rent it out.

The area of a dwelling house (part of a house) owned by a citizen with the right of private property, the number of rooms and floors, as well as the area of ancillary service buildings (basement, warehouse, bathroom, kitchen, etc.) may not be limited.

Article 123 of the Housing Code of the Azerbaijan SSR, entitled "Rights and obligations of family members of the owner of the dwelling house", stated that family members relocated by the owner of the dwelling house to his house have the right to use the living space at home, unless otherwise specified during their relocation. (Under the law, the homeowner's wife (husband), their children, and their parents were considered family members of the homeowner. Other persons living with the owner and running a common household with him could also be considered members of the owner's family).

Family members have the right to move their minor children to the living space provided to them by the owner; resettlement of other family members is allowed only with the consent of the owner. The right of these persons to use the living space shall be retained even in the event of termination of family relations with the owner of the dwelling house.

Disputes between the owner and his family members on the rules of use of the living space and the amount of participation in the expenses shall be resolved in court.

Articles 138-144 of the Housing Code of the Azerbaijan SSR were devoted to ensuring the protection of the housing stock, its operation and repair, Articles 145-146 to the issue of liability for violation of housing legislation, and Article 147 to the settlement of housing disputes.

The relations regulated by the Housing Code of the Azerbaijan SSR mainly coincided with the subject of civil law and were partially covered by administrative-legal norms.

In the last years of the existence of the USSR, beginning from mid-1989, the sale of apartments in the state and public housing began to the private ownership of citizens. Thus, the notarization of agreements on the alienation of apartments given to the private property of citizens and the issuance of notarized certificates of the right to inherit by will and law to such apartments began.

With the collapse of the USSR, fundamental changes took place in the economic and legal system of Azerbaijan. Law of the Republic of Azerbaijan dated November 9, 1991 "On property in the Republic of Azerbaijan", Law of the Republic of Azerbaijan dated January 26, 1993 "On privatization of housing stock in the Republic of Azerbaijan", Adoption of the Constitution of the Republic of Azerbaijan of November 12, 1995 and other normative legal acts can be considered as evidence of legal changes". Though certain types of real estate - land, buildings, apartments, etc are reflected in the Law of the Republic of Azerbaijan "On Property in the Republic of Azerbaijan" and the Law of the Republic of Azerbaijan "On Privatization of Housing in the Republic of Azerbaijan", the term "real estate" is not used in these normative legal acts. However, paragraph 3 of Article 29 of the Constitution of the independent Republic of Azerbaijan, adopted on November 12, 1995, states that everyone may own movable and immovable property. 


\section{Цивільне, підприсмницьке, господарське та трудове право}

Bibliographic references

1. Civil Code of the Azerbaijan SSR (1964). Baku: Huquq Publishing House, 2013, 540 p. (In Azerbaijani language).

2. Рясенцев В.А. Понятие права личной собственности, в книге «Право собственности». М.: Юридическая литература, $1980,164 \mathrm{c}$.

3. Шахматов В.П. Новое советское законодательство о браке и семье (часть первая). Томск: Томский государственный университет, 1969, 154 с.

4. Конституция (Основной Закон) CССР от 7 октября 1977 года. http://www. hist.msu.ru/ER/Etext/cnst1977.htm\#i

5. Constitution of the Azerbaijan Soviet Socialist Republic dated April 21, 1978. Baku: Azerneshr, 1978, 62 p. (In Azerbaijani language).

6. Аитовкин В.Н. Жилищное законодательство: вчера, сегодня, завтра // Жилищное право, 2010, № 6, с. 71-113

7. Collection of Decisions of the Plenum of the Supreme Court of the Azerbaijan SSR (1961-1983). Baku: Azerbaijan State Publishing House, 1985, 347 p. (In Azerbaijani language).

8. Vedomosti of the Supreme Soviet of the USSR, 1981, № 26, Art. 834 (In Russian language).

9. Vedomosti of the Supreme Soviet of the USSR, 1981, № 49, Art. 1286 (In Russian language).

10. Housing Code of the RSFSR of June 24, 1983. Vedomosti of the Supreme Soviet of the RSFSR, 1985, № 4, Art. 117 (In Russian language).
11. Housing Code of the Ukrainian SSR of June 30, 1983. http://online.zakon.kz/m/ Document/?doc_id=30418352 (In Russian language).

12. Comments on the Housing Code of the Kazakh SSR / Basin Yu.G., Suleimenov M.K., Tazutdinov R.S.; Edited by: Basin Yu.G. AlmaAta, 1987, 304 c. (In Russian language).

13. Housing Code of the Republic of Azerbaijan dated July 8, 1982. Baku: Ganun Publishing house, 2003, 108 p. (In Azerbaijani language).

Дадашов Эмин Теюб оглу - доктор фбилософии по праву, старший научный сотрудник Института права и прав человека Национальной академии наук Азербайджана

\section{ИСТОРИЯ РАЗВИТИЯ} ЗАКОНОДАТЕЛЬСТВА АЗЕРБАЙДЖАНА О НЕДВИЖИМОМ ИМУЩЕСТВЕ (60-е-90-е годы XX века)

В статье отмечается, что в последние годы существования СССР, начиная с середины 1989-го года, в Азербайджане началась продажа гражданам в личную собственность квартир в домах государственного и общественного жилищного фонда. В «Конституционном акте о восстановлении государственной независимости Азербайджанской Республики» от 18 октября 1991 года, в статьях 7-ой и 22-ой впервые был употреблен термин недвижимое имущество.

Ключевые слова: Право, кодекс, статья, имущество, законодательство. 